\title{
Positieve criminologie
}

\author{
Bob Hoogenboom
}

De Sala della Pace van het Palazzo Pubblico in het stadhuis van Siena, de ruimte waarin de 'Raad van Negen' vergaderde, bevat de beroemde allegorische voorstellingen van het goede en slechte bestuur door Ambrogio Lorenzetti. 'Securitas' in de positieve zin van het woord is hier onontbeerlijk voor vrede, harmonie en rechtvaardigheid van de stad en het omliggende platteland. De fresco's werden aangebracht in 1337-1339. Op het fresco van het goede bestuur zetelt een vrouw die symbool staat voor de rechtvaardigheid. Boven deze vrouw zweeft de wijsheid, die een enorme weegschaal vasthoudt die door de rechtvaardigheid precies in balans wordt gehouden. Vanaf de weegschaal lopen twee koorden, die door Concordia, symbool voor de eendracht, tot een dik touw worden gedraaid. Dit touw wordt doorgegeven aan 24 burgers. We zien vrouwen die de deugden uitbeelden: vrede, kracht, behoedzaamheid, ruimhartigheid, gematigdheid en rechtvaardigheid ('justitia'). Boven het hoofd van de heerser zien we nog drie onmisbare ingrediënten voor goed bestuur: geloof, hoop en liefde. Rechtsonder zien we een groepje gevangenen die door soldaten worden bewaakt, wachtend op berechting rechtvaardigheid is niet voor niets twee keer op het fresco afgebeeld. Boven het land zweeft een gevleugelde vrouwenfiguur die staat voor de securitas, oftewel de zekerheid, die goed bestuur met zich mee brengt.

De revitalisering van de liefdevolle taal binnen de criminologie door de positieve criminologie kent een lange - en rijke - traditie. 'Securitas' heeft niet alleen op deze fresco's een positieve betekenis. Behoefte aan veiligheid en zekerheid is volgens het model van Maslow - na lichamelijke behoeften - essentieel voor ons bestaan. Door de geschiedenis heen zien we in alle samenlevingen vormen van interne en externe veiligheid ontstaan. Interne veiligheid omvat (in)formele systemen van conflictregulering. Externe veiligheid is gericht op continuïteit van sociale en politieke systemen vis-à-vis bedreigingen van buitenaf.

In Recht als Schild van Perseus. Voordrachten over strafrechtstheorie uit 1991 gebruikt Joest 't Hart de fresco's om de grondslagen van het strafrecht te doordenken. Eerder deed 't Hart dat ook met René Foqué in Instrumentaliteit en rechtsbescherming (1990). Het schild van Perseus wordt door 't Hart gebruikt om aan te geven dat het recht een positieve waarde vertegenwoordigt, omdat het de burger beschermt tegen machtsmisbruik door de overheid. In de overgang van het feodale systeem en het absolutisme naar de nationale eenheidsstaat wordt willekeur van de koning, de adel en kerkelijke autoriteiten aan banden gelegd. Rechtsbescherming is de grondgedachte van de rechtsstaat die in de negentiende en twintigste eeuw geleidelijk wordt uitgebouwd. Daarbij zijn de ideeën van de Verlichting over machtenscheiding en politieke controle op de macht en verantwoording en democratie, die door de Amerikaanse en Franse revolutie in de praktijk zijn gebracht, ingegeven door een machtskritische instelling. 
De rechtsstaat is een experiment avant la lettre van wat we nu weer terugzien in de taal van positieve veiligheid. Niet louter instrumentele doeleinden als de war on crime, war on drugs, war on terror, targets, criminelen onderuit trekken of uitschakelen van ongure elementen zijn de primaire drijfveren. Maar gebeurt dit alles ook in de geest van de waarden van de rechtsstaat, de algemene beginselen van goed bestuur?

Foqué en 't Hart beargumenteren in Instrumentaliteit en rechtsbescherming dat de balans tussen deze twee kernwaarden in het gedrang komt wanneer het (straf)recht zijn machtskritische functie verliest. Dat gebeurt wanneer instrumentele doeleinden ondergeschikt worden gemaakt aan politiek-bestuurlijke doelstellingen. Instrumentaliteit gaat dan domineren en rechtsbescherming komt op het tweede plan. In perioden waarin dit gebeurt, ontstaat ruimte voor bezuinigingen op de strafrechtspleging en ruimte om meer en verdergaande bevoegdheden in het strafrecht en bijvoorbeeld in de wet op de inlichtingen- en veiligheidsdiensten aan te brengen. In het beleidsdenken raken dan, in de woorden van Foqué en 't Hart, de waarden van het recht die een beschermende en een machtskritische functie vervullen steeds verder buiten het gezichtsveld. De burger, of in ieder geval groepen burgers, worden in wij-zij-schema's gedrukt. De aloude sociologische inzichten over outsiders en zondebokken maken dan opgang.

In Recht als Schild van Perseus gebruikt 't Hart het fresco van het slechte bestuur om de gevolgen hiervan aan te geven. We zien een demonische tiran op de troon. Aan zijn voeten is een bok te zien, symbool van wellust. Boven zijn hoofd worden gierigheid, ijdelheid en overmoed, en aan weerszijden wreedheid, verraad en fraude uitgebeeld. Maar ook woede, verdeeldheid en oorlog. Aan de voeten van de tiran ligt een vastgebonden figuur die de rechtvaardigheid verbeeldt. De schalen van de weegschaal liggen los op de grond. De koorden tussen de machthebber en de burgers zijn verbroken. 'Securitas' zweeft niet langer boven het tafereel.

De nieuwe stroming binnen de criminologie met nieuwe taal over geloof, hoop, liefde, rechtvaardigheid, behoedzaamheid en ruimhartigheid is in feite een zoektocht naar het aloude begrip 'securitas' en de rechtsbeschermende waarden van de rechtsstaat. Hiermee zetten auteurs zich af tegen het louter instrumentele gedachtegoed waarin uitsluitend nog gebruik wordt gemaakt van negatieve taal. Een parallel kan worden getrokken met het begrip 'politie'. De etymologie hiervan is - net als 'securitas' - in wezen positief. In de Griekse Oudheid was politeia de wetenschap van het stadsbestuur. We zouden het nu bestuurskunde noemen: hoe richten we de samenleving in? Hoe garanderen we veiligheid en welzijn voor burgers? In de Griekse Oudheid diende het besturen van de stad gericht te zijn op rechtvaardigheid en harmonie tussen de rechten en plichten van burgers. De Grieken wezen door loting een poliarchos aan die met behulp van ambtenaren waakte over de zeden, openbare veiligheid, toezicht hield op markten en bijvoorbeeld de gewichten inspecteerde. Hierdoor werden burgers beschermd tegenover onwelwillende elementen. In het Ottomaanse rijk was de Bostan Bashi een van de vier politieofficieren die verantwoordelijk waren voor de keizerlijke landgoederen en paleizen, maar hij controleerde en bestuurde ('policing') een groot deel van de handel. Alle mogelijke regeringstaken vielen op de schouders van de politie. Van de controle op census-opgaven tot rapportages over de kwaliteit van het wegen- 
net (Swanson, 1975). In het pre-industriële Frankrijk had de politie tot taak de belastingen te innen en de watervoorzieningen en publieke gezondheid te controleren. Ook hier heeft politie een positieve betekenis, onder meer de bescherming van de volksgezondheid (Wolzendorff, 1918: 14).

In Duitsland ontwikkelt zich in de zeventiende en achttiende eeuw een nieuwe wetenschap: 'Polizei-wissenschaft'. 'Polizei' betekent hier bestuur in de breedste betekenis van het woord. En, het woord heeft een positieve betekenis: inrichting van de samenleving en bescherming van lijf en goederen van burgers en de instandhouding van goede zeden. Centraal staat het begrip 'Polizeigedanke'. Dit is gebaseerd op het principe van 'der allgemeine Wohlfahrt'. Zo worden in 1691 in Pruisen voorschriften uitgevaardigd om de landbouw te reguleren. Een onderscheid wordt hierbij gemaakt tussen 'wohlfartpolizei' en 'sicherheitspolizei'. De oorspronkelijke betekenis van politie ligt in de eerste betekenis: bewerkstelligen van welzijn en welvaart voor burgers. Het strafrecht en de inlichtingenwereld doen dit ten aanzien van criminaliteit en de nationale veiligheid. Met de opkomst van de verzorgingsstaat is de overheid zich intensief gaan bemoeien met het bevorderen van welzijn en welvaart in het sociaaleconomische domein. Van het Kinderwetje van Van Houten tot aan de oprichting van de Autoriteit Consument en Markt geeft de Staat inhoud aan de securitas- en oorspronkelijke politiegedachte. Beide zijn in de kern positief.

'Politeia', 'polis', 'policy' en 'policing' hebben in de geschiedenis lange tijd een veel bredere - en positievere - betekenis gehad dan vandaag de dag: bestuur in algemene zin en inrichting van de samenleving. Relevant hierbij is dat politiestelsels langs een continuüm kunnen worden geplaatst waarin de belangen van de Staat aan het ene uiterste kunnen worden geplaatst en die van de burger aan het andere uiterste. De politiestaat in dictatoriale regimes, nazi-Duitsland en communistische landen (Stasi in Oost-Duitsland) zijn primair ingericht om de politieke belangen van de macht te dienen. In westerse landen is veelal sprake van een mengvorm. Nationale veiligheid is belegd bij inlichtingen- en veiligheidsdiensten ('high policing') en orde- en rechtshandhaving en hulpverlening aan hen die dat behoeven ('low policing') worden uitgeoefend door de politie.

Beide politiefuncties vervullen een 'securitas-functie' in de klassieke - positieve betekenis van het woord. Orde- en rechtshandhaving en hulpverlening zijn wezenlijk voor de voorspelbaarheid, betrouwbaarheid en continuïteit van het openbare leven. 'Securitas' wordt positief ingevuld door de overheid middels autoriteiten, inspecties, bijzondere opsporingsdiensten, stadstoezicht, boa's en politie en justitie, maar evenzeer door particuliere beveiliging. Als patiënt vind ik het een geruststellende gedachte dat er toezicht is op de gezondheidszorg. Als werknemer vind ik het goed dat er toezicht is op arbeidsomstandigheden. Als consument vind $\mathrm{ik}$ het prettig dat kartelvorming de aandacht heeft. Als consument vind ik het van belang dat er controles plaatsvinden in de voedselketen.

Stel je voor dat de KMar de controle op Schiphol opheft, de politie de noodhulp stopzet, de dienst Stadstoezicht markten, parkeren en vuilafval niet meer controleert, de AFM, de ACM en de vele inspecties zich niet meer richten op de handel en wandel van financiële dienstverleners, het onderwijs, de gezondheidszorg, de telecommarkt, de opslag en het gebruik van persoonsgegevens of het milieu? Of 
dat de veiligheidsindustrie niet meer fouilleert bij risicowedstrijden in het voetbal? De AIVD niet langer radicaliseringsprocessen in kaart brengt dan wel samenwerkt met buitenlandse diensten om incidenten te voorkomen? Al deze 'securitas- en politiefuncties' zijn dermate verweven met honderden sociale processen, dat we ze feitelijk niet meer waarderen om hun positieve betekenis.

De 'securitas- en politiefunctie' in de moderne samenleving zijn uitgebreid, gediversifieerd en in wezen nog altijd passend in de traditie van 'politeia', 'de Polizeigedanke', de uitgangspunten van het 'Wohlfahrts-ideaal': de overheid als beschermer van de burger. In de zin dat het welzijn van burgers is gediend. De securitasfunctie en de politiefunctie vervullen nog altijd een rol zoals in de fresco's van het goede bestuur in 1337-1339 is bedoeld, mits er sprake is van behoedzaamheid, ruimhartigheid, gematigdheid en rechtvaardigheid; en ook als mensen belast met de 'securitas' en politie de drie andere onmisbare ingrediënten voor een goed bestuur, geloof, hoop en liefde, in hun houding en gedrag verpersoonlijken.

Dit gaat fout, in de geest van de 'Polizeiwissenschaft' en Foqué en 't Hart, als de 'Wohlfahrt-gedachte' ondergeschikt wordt gemaakt aan de 'Sicherheit-gedachte'. Indien instrumentele belangen van de Staat prevaleren boven de belangen van de burger, dan gaan instrumentele doelstellingen ten koste van rechtsbeschermende waarden. Dus als de Arubaan Mitch Henriquez door een nekklem door politiemensen overlijdt, schiet de 'securitas' door. Dan verliest veiligheid zijn positieve betekenis. Dat gebeurt ook wanneer in de 'war on terror' over de hele wereld 'verdachten' van straat worden geplukt en zonder vorm van berechting naar Guantanamo Bay worden verplaatst om daar weg te kwijnen. Het gebeurt als de politie zich schuldig maakt aan discriminatie. Of indien 'verdachten' in strafzaken in de maalstroom van tunnelvisie door de recherche geraken en ontlastend bewijs niet zijn weg vindt naar de rechter en onschuldige 'verdachten' jarenlang in de gevangenis zitten, denk aan de Schiedammer Parkmoord, de Puttense moordzaak, Guildford Four, en de Birmingham Six.

In sommige perioden in de geschiedenis ontstaat een taal die bol staat van noodzakelijkheid en machismo. Het is de taal vol negativiteit en ronkende oorlogssymboliek; taal die ontspeend is van inlevingsvermogen, relativiteit, ontspanning en empathie. Het is de taal die door de machthebbers wordt gebruikt om de 'Wohlfahrt-gedachte' en rechtsbeschermingsfunctie van de rechtsstaat af te breken, om deze te vervangen door een louter instrumentele opvatting over de inrichting van de samenleving. Edward Shils (1956) analyseert een dergelijke periode in de Amerikaanse geschiedenis (de communistische heksenjachten gedurende de Koude Oorlog). Volgens Shils steunt de democratie op drie pilaren: geheimhouding, individuele privacy en openbaarheid. Er is in een rechtsstaat niets mis met bepaalde vormen van functionele geheimhouding. De AIVD noch een advocaat kan functioneren zonder gradaties van confidentialiteit. Individuele privacy is een groot goed, maar is nooit absoluut. En openbaarheid van bestuur is functioneel voor het democratisch proces, maar is nooit absoluut. De drie pilaren dienen in balans te zijn. Het gaat fout volgens Shils als die balans verstoord raakt. In de McCarthyperiode, de senator die leiding gaf aan het House Committee of Un-American Activities in de jaren 1950, gaat de overheid steeds meer in het geheim opereren en verzamelt informatie over burgers, ook van naar later zal blijken veel onschuldige 
burgers. Het gevolg is dat de privacy van burgers door de overheid niet langer als een kernwaarde van de rechtsstaat wordt ervaren. Veel van wat de overheid doet om het 'gevaar' het hoofd te bieden wordt steeds minder zichtbaar voor controlerende organen in de democratie. De taal over de dreigingen is dan eendimensionaal, staat bol van de stereotypen. Er is geen ruimte voor nuance, noch voor relativering of humor. De deugden van het goede bestuur worden flets en er is sprake van een geleidelijke vervaging tussen de fresco's van het goede en het slechte bestuur.

Daarom is de positieve criminologie me sympathiek, omdat wordt gewezen op de versimpeling van de werkelijkheid van goed en kwaad in boze, agressieve, zwartwit woorden. Maar ze is dat ook, omdat weer een verbinding wordt gelegd met de positieve betekenis van 'securitas' en politie. De tragiek van de positieve criminologie is echter dat deze tot ontwikkeling komt in een tijdvak waarin de veiligheidstaal verhardt. Ik zie de tragiek in twee bedrijven.

In het eerste bedrijf is er sprake van een sterke politisering van veiligheid. Door terrorisme en door de vluchtelingenstromen krijgt de veiligheidstaal nog meer kenmerken van alles waartegen de positieve criminologie zich afzet. De taal wordt nog hardvochtiger. In heel Europa doen zich politieke verschuivingen voor die ontvankelijk zijn voor wij-zij-denken, grenzen sluiten, afremmen, straffen, opsluiten, terugsturen en verdere militarisering van veiligheid. Deze politisering draagt ingrediënten in zich om de 'securitas' te laten kantelen van goed naar slecht bestuur, van 'Wohlfahrts- naar Sicherheitspolizei', van rechtsbescherming naar instrumentaliteit en van een verstoring van het evenwicht tussen de drie pilaren van de democratie. De positieve taal valt op steenachtige grond net als het zaad van het Evangelie. In Markus 4:6 lezen we: 'En het andere viel op het steenachtige, waar het niet veel aarde had en het ging terstond op, omdat het geen diepte van aarde had. Maar als de zon opgegaan was, zo is het verbrand geworden, en omdat het geen wortel had, zo is het verdord.'

In het tweede bedrijf komt de positieve taal tot ontwikkeling in een academisch klimaat dat is gekoloniseerd door de bureaucratie. Ik herlas laatst delen van The Sociological Imagination van C. Wright Mills uit 1959. Het hoofdstuk The Bureaucratic Ethos is deerniswekkend. Hier wordt uit de doeken gedaan hoe de bureaucratische geest de sociale wetenschappen heeft gedomesticeerd en worden woorden als 'conservatief', 'manipulatief, 'routinisering', 'efficiency' en 'rationalisering' gebruikt. Aanstellingen, subsidies, acceptatie van artikelen, bezoek aan internationale congressen en het intellectuele debat zijn afhankelijk geworden van 'academic cliques'. Deze kliek bepaalt de taal, de toon en sfeer en de grenzen van wat goede wetenschap is. Deze bureaucratische ethos wordt (on)bewust sterk beïnvloed door de politieke context, door financiering en toegang tot onderzoeksobjecten. 'And now, for something completely different', in dit geval zal positieve criminologie een ontvangst ten deel vallen als witteboordencriminaliteit, het abolitionisme, victimologie, preventie, groene criminologie en mediation. Positieve criminologie zal worden geduld als hofnarren aan het middeleeuwse hof, door de mainstream worden gemarginaliseerd en blijvend bedreven worden door een handvol believers. Alleen als deze persisteren in hun kruistocht, zal er sprake zijn van acceptatie. Zoals bijvoorbeeld met de victimologie. 
Tot slot. Toch is de positieve criminologie mij niet alleen sympathiek, maar acht ik het ook een noodzakelijke beweging. Mits deze beweging het academisch milieu ontstijgt en sociale wetenschappers zich meer gaan bewegen in politieke en maatschappelijke kringen en publicatiedrift/-verplichtingen combineren met een meer activistisch burgerschap. Zo wordt binnen politieke partijen nagedacht over het veiligheidsbeleid na de verkiezingen. En worden weer woorden als rechtsstaat, privacy en mensenrechten gebezigd. Ook in de wereld van vrijwilligers, vluchtelingenwerk, sociale hulpverlening, buurt- en wijkzorg, gevangenissen, en resocialisatie kan de taal van de positieve criminologie inspirerend, motiverend en vernieuwend werken. Maar dat vereist wel engagement, zoek dat woord maar weer eens op.

\section{Literatuur}

Foqué, R. \& A.C. 't Hart (1990), Instrumentaliteit en rechtsbescherming: grondslagen van een strafrechtelijke waardendiscussie. Arnhem: Gouda Quint.

Hart, A.C. 't (1991), Recht als Schild van Perseus. Voordrachten over strafrechtstheorie. Arnhem: Gouda Quint.

Shils, E. (1956), Publicity, privacy and secrecy: Their equilibrium and its disruption. In: E. Shils, The Torments of Secrecy. Glencoe, Ill.: Free Press, 21-35.

Swanson, G.W. (1975), The Ottoman Police. In: G.L. Mosse (ed.), Police Forces in History. Beverly Hills: Sage, 17-38.

Wolzendorff, K. (1918), Der Polizeigedanke des Modernen Staates. Breslau. 